\title{
Efficacy of Presepsin as a Biomarker of Sepsis and Its Prognostic Value for Prediction of Mortality
}

\section{Bir Sepsis Biyobelirteci Olarak Presepsinin Etkinliği ve Mortalite Öngörüsü için Prognostik Değeri}

\author{
๑ İbrahim Akkoç, ๑ Zümrüt Mine Işık Sağlam* • Đ Öznur Şen, ๑ Nurdan Aydın, \\ ๑ Macit Koldaş*, ๑ Mehmet Toptaş, ๑ Sinan Uzman
}

University of Health Sciences Turkey, Haseki Training and Research Hospital, Clinic of Anesthesiology and Reanimation, Istanbul, Turkey

*University of Health Sciences Turkey, Haseki Training and Research Hospital, Clinic of Medical Biochemistry, Istanbul, Turkey

\begin{abstract}
Aim: We aimed to determine the efficacy of presepsin (PRE) as a biomarker of sepsis and to asssess its prognostic value for prediction of mortality were determined.

Methods: Selected clinical data of 21 patients admitted to intensive care unit for systemic inflammatory response syndrome (SIRS), sepsis and septic shock were collected. APACHE-II score, blood culture results and WBC and CRP measured at baseline, procalcitonin (PCT) and PRE measured at baseline and on days 2 , 4, and 7, and mortality of patients were recorded.

Results: Compared to SIRS, sepsis and septic shock caused comparable increases in the APACHE II scores and mortality rates. The PRE values of the septic shock patients were significantly higher as compared to the sepsis and the SIRS patients at baseline and on day 2. Moderate or high correlations among both the PCT and PRE values measured at baseline and on days 2,4 , and 7 were detected. Overall, the diagnostic and prognostic efficacies of PRE were comparable to those of PCT.
\end{abstract}

Conclusions: During differential diagnosis, follow-up and prediction of mortality risk of patients for SIRS, sepsis and septic shock, findings of current study support that PRE possesses a merit to be used as a biomarker with comparable efficacy with PCT.

Keywords: Systemic inflammatory response syndrome (SIRS), sepsis, septic shock, APACHE-II, presepsin, procalcitonin, C-reactive protein (CRP), white blood count (WBC)

Öz

\begin{abstract}
Amaç: Amacımız bir sepsisbiyobelirteci olarak presepsinin (PRE) etkinliğini değerlendirmek ve mortalite öngörüsündeki prognostik değerini belirlemekti.
\end{abstract}

Yöntemler: Sistemik enflamatuvar cevap sendromu (SIRS), sepsis ve septik şok ile yoğun bakım ünitesine kabul edilen 21 hastanın seçilen bulguları toplandı. APACHE II skorları, kan kültürü sonuçları ve biyobelirteçler olarak lökosit ve CRP'nin ilk gün değerleri ile prokalsitonin (PCT) ve PRE'nin ilk gün ve gün 2 , 4, ve 7 değerleri ve mortalite durumu kaydedildi.

Bulgular: Sepsis ve septik şok hastalarının relatif olarak yükselmiş APACHE-II skorları ve mortalite oranları, SIRS hastalarınınkilerdenfazla idi. Septik şok hastalarının PRE düzeyleri, ilk gün ve ikinci günde sepsis ve SIRS hastalarınınkine göre anlamlı derecede yüksekti. Hem PCT hem de PRE'nin ilk gün ve gün 2, 4, ve 7 değerleri birbiri ile orta-yüksek derecede ilişkili idi. Genel olarak bakıldığında, ilk gün ve izlemde kullanıldığında ve mortalite öngörüsü için dikkate alındığında PRE'nindiagnostik ve prognostik etkinliği PCT'ye yakın bulundu.

Sonuç: Bu araştırmanın sonuçları PCT ile oldukça benzer etkinliğe sahip bir biyobelirteç olarak PRE'nin, SIRS, sepsis ve septik şok bulunan hastaların ayırıcı tanısı, izlemi ve mortalite risk öngörüsü sırasında kullanılabilirliğine işaret etmektedir.

Anahtar Sözcükler: Sistemik enflamatuvar cevap sendromu (SIRS), sepsis, septik şok, APACHE-II, presepsin, prokalsitonin, C-reaktif protein (CRP), lökosit sayısı
Address for Correspondence/Yazışma Adresi: İbrahim Akkoç, University of Health Sciences of Turkey, Haseki Training and Research Hospital, Clinic of Anesthesiology and Reanimation, İstanbul, Turkey E-mail: ibrakkoc@gmail.com ORCID: orcid.org/0000-0002-3614-5274

Received/Geliş Tarihi: 19 February 2020 Accepted/Kabul Tarihi: 24.02.2020
${ }^{\circ}$ Copyright 2020 by The Medical Bulletin of istanbul Haseki Training and Research Hospital The Medical Bulletin of Haseki published by Galenos Yayınevi. ${ }^{\bullet}$ Telif Hakkı 2020 Istanbul Haseki Eğitim ve Araştırma Hastanesi Haseki Tıp Bülteni, Galenos Yayınevi tarafından yayınlanmıştır. 


\section{Introduction}

Sepsis is a clinical syndrome of life-threatening organ dysfunction caused by a disorganized host inflammatory response to infection. It is among the most important causes of morbidity and mortality in intensive care units (ICUs). The clinical term of systemic inflammatory response syndrome (SIRS) is used to describe the complex pathophysiologic response to infection in patients before the detection of infectious agents, as it has long been used to identify early sepsis. In septic shock, there is a critical reduction in tissue perfusion; acute failure of multiple organs, including the lungs, kidneys, and liver, can occur. Septic shock, a subset of sepsis, has significantly increased mortality due to persistent hypotension (defined as the need for use of vasopressors and high level of serum lactate despite adequate fluid support $(1,2)$.

The cornerstone of proper management in patients with sepsis is the early determination of mortality risk in the ICU. For this purpose, the application of severity scores and serum biomarkers are used at admission and followup. The most widely applied score is the Acute Physiology and Chronic Health Evaluation II (APACHE II). However, APACHE II scoring may be misleading in some clinical situations. In younger patients with severe sepsis but without chronic organ failures, the APACHE II score may be relatively low in sepsis patients with a risk of higher mortality. In contrast, in older patients with sepsis but with chronic organ failures, it may be higher even when the mortality risk is relatively low (3).

After early diagnosis of sepsis, goal-directed management may reduce their morbidity and mortality (4). Blood culture is the gold standard for diagnosing sepsis; however, it takes a long time to obtain its result. Depending on the previous antibiotic treatment, 30\% of sepsis patients tend to be diagnosed with bacteremia (5). In sepsis, traditional systemic inflammatory variables include leukocytosis [white blood cellcount $(\mathrm{WBC})>12,000 / \mu \mathrm{L}$ ] or leukopenia (WBC<4,000/ $\mathrm{LL})(6,7)$.

There is a need for successful and new biomarkers with satisfactory sensitivity and specificity in order to achieve early diagnosis and sound estimation of the prognosis for the patients with sepsis. For this purpose, the most frequently studied biomarkers are procalcitonin (PCT), interleukin 6 (IL-6), tumor necrosis factor, C-reactive protein (CRP), and WBC (8).

Presepsinis a recently defined infection biomarker, which is a $13 \mathrm{kDa}$ fragment of the $\mathrm{N}$-terminal of soluble CD14. It is secreted into the blood after the activation of monocytes in response to several types of infections (9-11). Presepsinappeared to be comparable to other inflammatory biomarkers, including CRP, PCT, and IL-6, in the diagnosis of sepsis and its diagnostic performance superior to conventional markers and blood culture $(11,12)$. However, it is being proposed that presepsin, one of the newly exploited biomarkers, not only has a higher sensitivity and specificity but also assists in predicting the severity and the outcome more reliably $(13,14)$.

Presepsin needs further study to have a place in the armamentarium of intensive care physicians. When presepsin added among the diagnostic tests performed in the diagnosis and management of patients with sepsis types, it is possible to obtain an increase in the survival of these patients. We aimed (1) to determine the efficacy of presepsin as a biomarker of sepsis relative to those of WBC, CRP, and PCT in SIRS, sepsis, and septic shock; (2) to test its correlation with the APACHE-II scores; and (3) to assess its prognostic value for prediction of mortality were determined.

\section{Materials and Methods}

This retrospective study was conducted at the Haseki Training and Research Hospital with 21 adult patients who were treated at the ICU with diagnoses of SIRS, sepsis and septic shock. The approval of the Human Research Ethics Committee of our institution was obtained (decision no: 242, date: 26.09.2018).

The exclusion criteria were: recent cardiac resuscitation; severe head trauma; nephrotic syndrome; cirrhosis; burns or having been diagnosed with New York Heart Association class III-IV cardiac failure; HIV infection; presence of neutropenia; defined as $<1000$ neutrophils/ $\mathrm{mm}^{3}$; constantly use of antihypertensives related to angiotensin; recent use of heparin medications; longterm corticosteroid use; requirement of enteral nutrition; and women with pregnancy or breast-feeding. After the informed consent of patients or relatives, from the electronic hospital records of patients, selected clinical variables of the patients were collected. The patients were selected in this study on the basis of the criteria defined by The American College of Chest Physicians/Society of Critical Care Medicine Consensus Conference (15-17). Hence the selection criteria consisted of detection of two or more of the following SIRS symptoms within the latest 6-24 hours of a known or suspected infection, such as having a core temperature of $>38^{\circ} \mathrm{C}$ or $<36{ }^{\circ} \mathrm{C}$; heart rate of $<90$ beats/min; respiratory rate of $<20$ breaths/min; arterial partial pressure of carbon dioxide $<32 \mathrm{mmHg}$ or the requirement for mechanical ventilation for an acute pathological process; a white blood cell count $>12,000 / \mu \mathrm{L}$ or $<4,000 / \mu \mathrm{L}$ or observation of more than $10 \%$ immature neutrophils. SIRS patients with positive blood cultures were included in patients with sepsis.

Sepsis patients were required to have signs of more than one organ dysfunction $(15,16,18)$. The following 
anomalies were identified with severe sepsis: (1) cardiovascular anomalies as arterial systolic blood pressure less than $90 \mathrm{mmHg}$ or mean arterial pressure less than $70 \mathrm{mmHg}$ that responds to administration of intravenous fluid; (2) renal dysfunction with oliguria of less than 0.5 $\mathrm{mL} / \mathrm{kg}$ per hour despite adequate fluid resuscitation; (3) respiratory anomaly of $\mathrm{PaO}_{2} /$ fraction of inspired oxygen being less than 250; (4) hematological anomalies as platelet count of less than $80,000 / \mathrm{L}$ or a decline of $50 \%$ in platelet count from highest value recorded over the previous 3 days; (5) unexplained metabolic acidosis with a $\mathrm{pH}$ of 7.30 or base deficit of $5.0 \mathrm{mEq} / \mathrm{L}$ and plasma lactate level exceeding 1.5 times upper limit of normal for the reporting laboratory; (6) pulmonary artery wedge pressure being less than $12 \mathrm{mmHg}$ or central venous pressure of less than $8 \mathrm{mmHg}$ with adequate fluid resuscitation; and (7) acute alteration of mental status.

Septic shock was defined as sepsis with hypotension, in addition to signs of organ dysfunction, when recording a systolic blood pressure of $<90 \mathrm{mmHg}$ or its reduction by $40 \mathrm{mmHg}$ or more from the baseline in the absence of other causes for hypotension, despite adequate fluid resuscitation; or when the use of inotropics or vasopressors were needed to maintain a systolic blood pressure of more than $90 \mathrm{mmHg}$ or a mean arterial pressure of more than $70 \mathrm{mmHg}(19,20)$.

Blood specimens were collected immediately after admission to the ICU for blood culture and assessment of the levels of biomarkers (WBC, CRP, PCT, and presepsin), which was repeated on days 2, 4, and 7 after the admission of patients to the ICU. Hemodynamic parameters, arterial blood gases, ventilation parameters, fluid balance, vasoactive agent usage, antibiotic therapy, and standard laboratory tests were followed up daily. APACHE-II score was determined within the first 24 hours after admission to the ICU. The APACHE-II scores and the mortality and survival incidences at the ICU were evaluated on the basis of the three diagnostic groupings of SIRS, septic shock and sepsis.

\section{Biomarker Measurements}

presepsin measurements were performed in whole blood specimens collected into EDTA tubes, using PathfastPresepsin Assay Kit with Pastfast Analyzer (Mitsubishi Chemical, Japan). Measurements of PCT and CRP were carried out in SST serum (BD, USA); with the PTC assay (DiaSorin, Italy), and CRP Assay (Backman, USA). All of the procedures were conducted according to the manufacturer's instructions.

\section{Statistical Analysis}

SPSS software (IBM SPSS, Version 22.0, IBM Corporation, Armonk, NY, USA) was used for the statistical analyses on the data. Descriptive statistics consisted of the counts for the categorical variables and median with interquartile range and maximum and minimum for the numerical variables. During statistical analyses, MannWhitney, Kruskal-Wallis ANOVA, and Spearman correlation tests were performed. The $p$ value of $<0.05$ was accepted as statistical significance.

\section{Results}

In the study population, the rates of non-survivors were $1 / 11(9.1 \%), 2 / 6(33.3 \%)$, and $2 / 6(33.3 \%)$ in patients with SIRS, sepsis, and septic shock. As a total, there were five non-survivors and 16 survivors in the study population. The median age of participants was 64 (3393) and male/female ratio of them was $14 / 7$. With sepsis and septic shock, the rate of non-survivors was increased but this difference was not reached statistical significance ( $p>0.05)$. As presented in Table 1, the rates of culture positivity in the blood, tracheal, and urine samples of the study population were $38.1 \%, 47.6 \%$, and $33.3 \%$, respectively. There was no significant difference among these rates $(p>0.05)$.

Figure 1 presents the median APACHE II scores of patients with SIRS $(n=9)$, sepsis $(n=6)$, and septic shock $(n=6)$. The median APACHE II score of patients with SIRS was found significantly lower than those of the patients with sepsis and septic shock [15 (12.5-21.5) vs 23 (22.7$28.5)$ and 24 (22-27), respectively); $p<0.05]$. The median APACHE II scores of patients with sepsis and septic shock were found similar [23 (22.7-28.5) and 24 (22-27), respectively; $p>0.05]$.

Table 2 displays the association of the APACHE II score with studied biomarkers $(n=21)$. There was no significant correlation of the APACHE \| score with the CRP and

\begin{tabular}{|l|l|}
\hline \multicolumn{2}{|l|}{ Table 1. Blood, tracheal and urine culture results of participants } \\
\hline Culture type & Patients $(\mathbf{n})$ \\
\hline Blood culture (positive/negative) & $8 / 13(38.1 \%)$ \\
\hline Methicillin resistant staphylococcus aureus & 4 \\
\hline Candida albicans & 3 \\
\hline Pseudomonas aeruginosa & 1 \\
\hline Tracheal culture (positive/negative) & $10 / 11(47.6 \%)$ \\
\hline Pseudomonas aeruginosa & 8 \\
\hline Klebsiella pneumoniae & 1 \\
\hline Acinetobacter & 1 \\
\hline Urine culture (positive/negative) & $7 / 14(33.3 \%)$ \\
\hline Escherichia coli & 4 \\
\hline Acinetobacter & 2 \\
\hline Candida albicans & 1 \\
\hline n: Number & \\
\hline
\end{tabular}


WBC measured at baseline and PCT and presepsin values measured at baseline and on days 2, 4, 7 in the study population.

Figure 2 shows the median WBC and CRP values of patients with SIRS, sepsis, and septic shock. In the patients with SIRS, sepsis, and septic shock, the median WBC [18 (12.2-25.2), 12.8 (9.5-21.8), and 23 (10.333.1), respectively) and CRP [24.4 (9.1-68.0), 92 (19.8136), and 31.4 (118.5-93.3), respectively] values were found comparable $(p>0.05)$. As seen in the presentation,

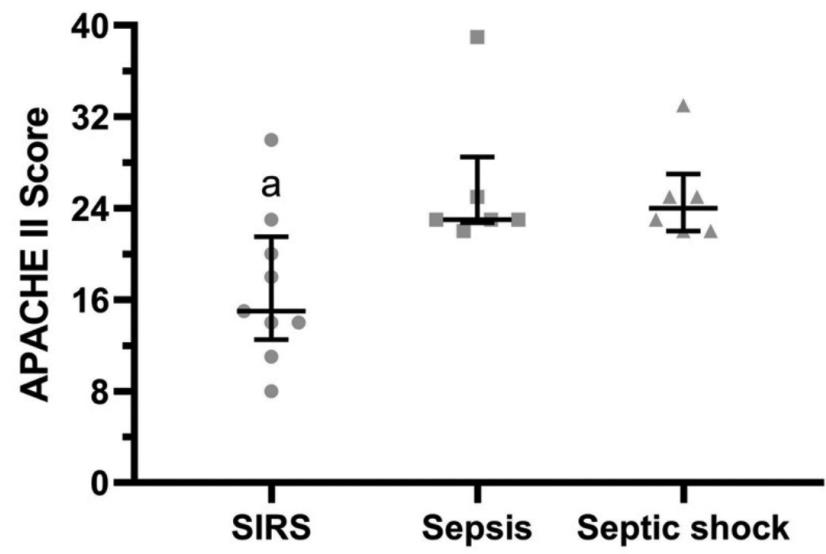

Figure 1. APACHE II scores of patients with SIRS ( $n=9)$, sepsis $(n=6)$, and septic shock $(n=6)$. Data were presented as median with interquartile range of $25-75 \%$. The median APACHE II score of patients with SIRS was found significantly lower (a) than compared to the patients with sepsis and septic shock $(p<0.05)$

APACHE II: Acute Physiology and Chronic Health Evaluation II, SIRS: Systemic inflammatory response syndrome

Table 2. Correlation coefficients between APACHE II and studied sepsis markers according to time points in the study population $(\mathrm{n}=\mathbf{2 1})$

\begin{tabular}{|l|l|l|l|}
\hline & Time points & $\begin{array}{l}\text { Correlation } \\
\text { coefficient of } \\
\text { APACHE II score }\end{array}$ & Significance \\
\hline CRP & Baseline & 0.066 & NS \\
\hline WBC & Baseline & 0.252 & NS \\
\hline PCT & Baseline & 0.023 & NS \\
\hline- & Day 2 & 0.104 & NS \\
\hline- & Day 4 & 0.080 & NS \\
\hline- & Day 7 & -0.086 & NS \\
\hline PRE & Baseline & 0.181 & NS \\
\hline- & Day 2 & 0.128 & NS \\
\hline- & Day 4 & 0.162 & NS \\
\hline- & Day 7 & 0.256 & NS \\
\hline
\end{tabular}

CRP: C-reactive protein, WBC: White blood count, PCT: Procalcitonin, and PRE: Presepsin, APACHE II: Acute Physiology and Chronic Health Evaluation II, n: Number $N S$; not significant at a $p$ value of less than 0.05 .

There were no significant correlations of the APACHE || score and studied biomarkers. these parameters did not follow similar pattern according to the severity of disease and in addition, there was no significant correlation between them in the study population ( $p>0.05$ ).

Figure 3 presents the PCT and presepsin values of non-survivors and survivors measured at baseline during admission and 2, 4, and 7 days later after admission. Kruskal-Wallis ANOVA test revealed no significant difference among the PCT values measured at baseline and on days 2, 4, and 7 of both the nonsurvivors and survivors ( $p>0.05)$. When the PCT values of non-survivors and survivors were compared with the Mann-Whitney test, there was no significant difference ( $p>0.05$ ). The Kruskal-Wallis ANOVA test demonstrated no significant difference among the presepsin values measured at baseline and on days 2, 4, and 7 of both the non-survivors and survivors ( $p>0.05)$. The MannWhitney test revealed no significant difference between the non-survivors and survivors regarding the presepsin
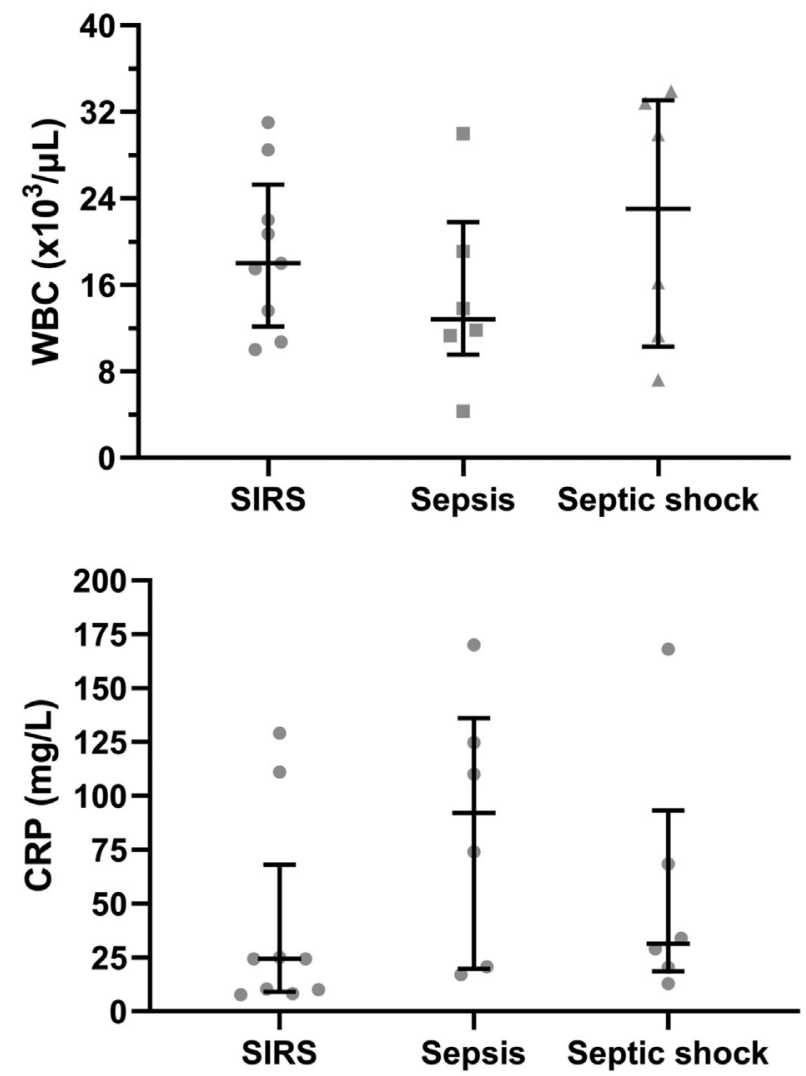

Figure 2. WBC and CRP values of patients with SIRS ( $n=9)$, sepsis $(n=6)$, and septic shock $(n=6)$. Data were presented as median with interquartile range of 25-75\%. The median WBC and CRP values of patients with SIRS, sepsis, and septic shock were found comparable $(p>0.05)$

WBC: White blood cell, CRP: C-reactive protein, SIRS: Systemic inflammatory response syndrome 
values measured at baseline and on days 2,4 , and 7 (>0.05).

In Figure 4, the PCT and presepsin values of patients with $\operatorname{SIRS}(n=9)$, sepsis $(n=6)$, and septic shock $(n=6)$ were displayed. Although there were, overall, decreases
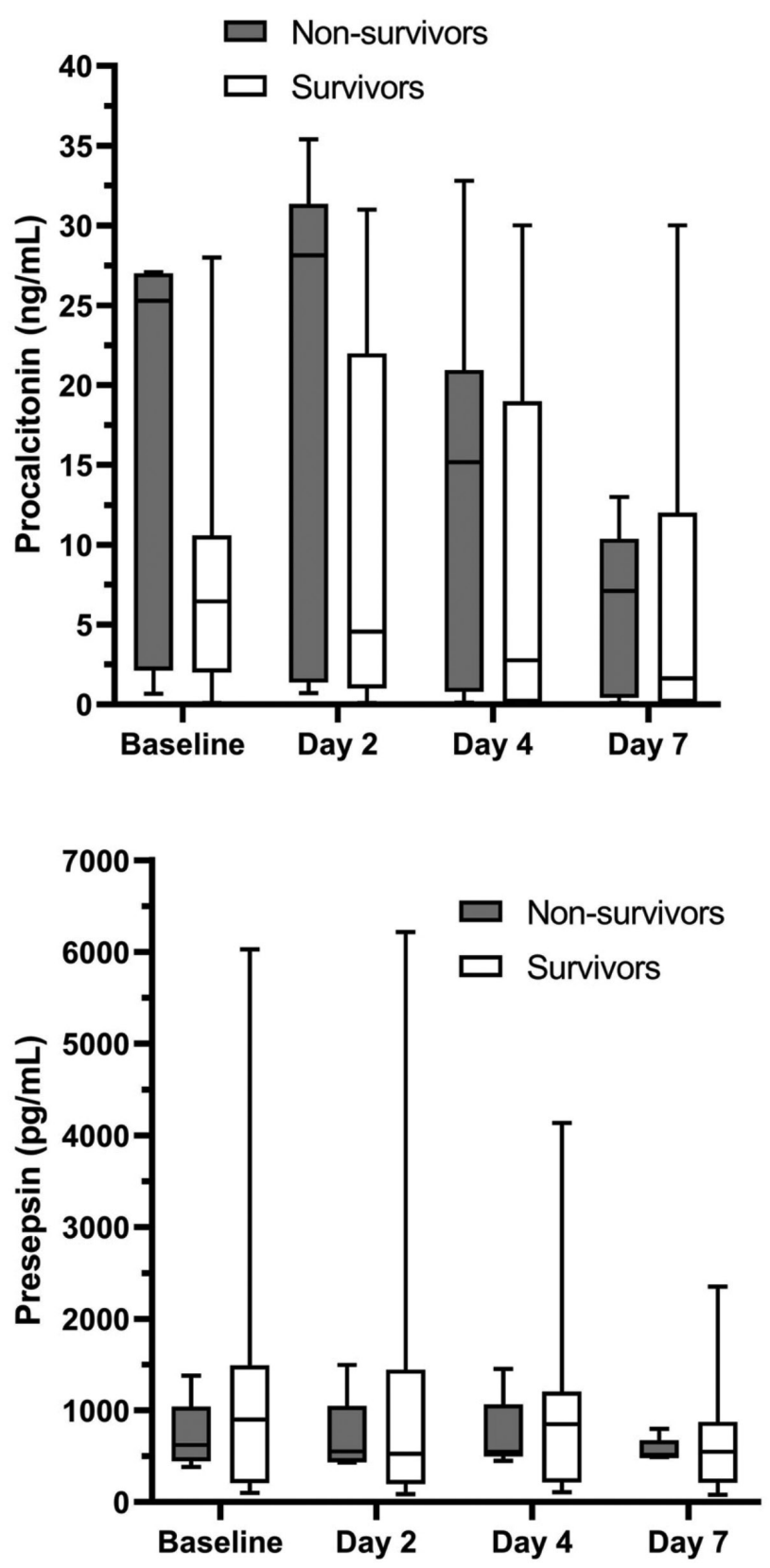

Figure 3. PCT and presepsin values of non-survivors $(n=5)$ and survivors ( $n=16)$ measured at baseline during admission and 2, 4, and 7 days later after admission. Data were presented as median with interquartile range of $25-75 \%$ and min-max values. Overall, there was no significant difference between the study subjects regarding the PCT and presepsin values $(>0.05)$

PCT: Procalcitonin, min: Minimum, max: Maximum in the PCT and presepsin levels from baseline to day 7, these differences were not reached statistical difference ( $p>0.05$ ) except the presepsin values of patients with SIRS at baseline and on day 2 were significantly higher compared to those of septic shock $(p<0.05)$.

After Spearman correlation analyses (Table 3), we found that moderate or high correlations among both the PCT and presepsin values measured at baseline and on days 2,4 , and $7(p<0.05)$. There was a significant correlation between the PCT and presepsin values measured only on day 7 ( $r=0.56, p<0.05)$; however, there was no significant correlation between these parameters measured on other time points.

\section{Discussion}

In the current study, we assessed the admission and follow-up findings of patients with SIRS, sepsis, and septic shock in the ICU. In moderate percentage of patients, the positivity of microbiological culture was detected. Relative
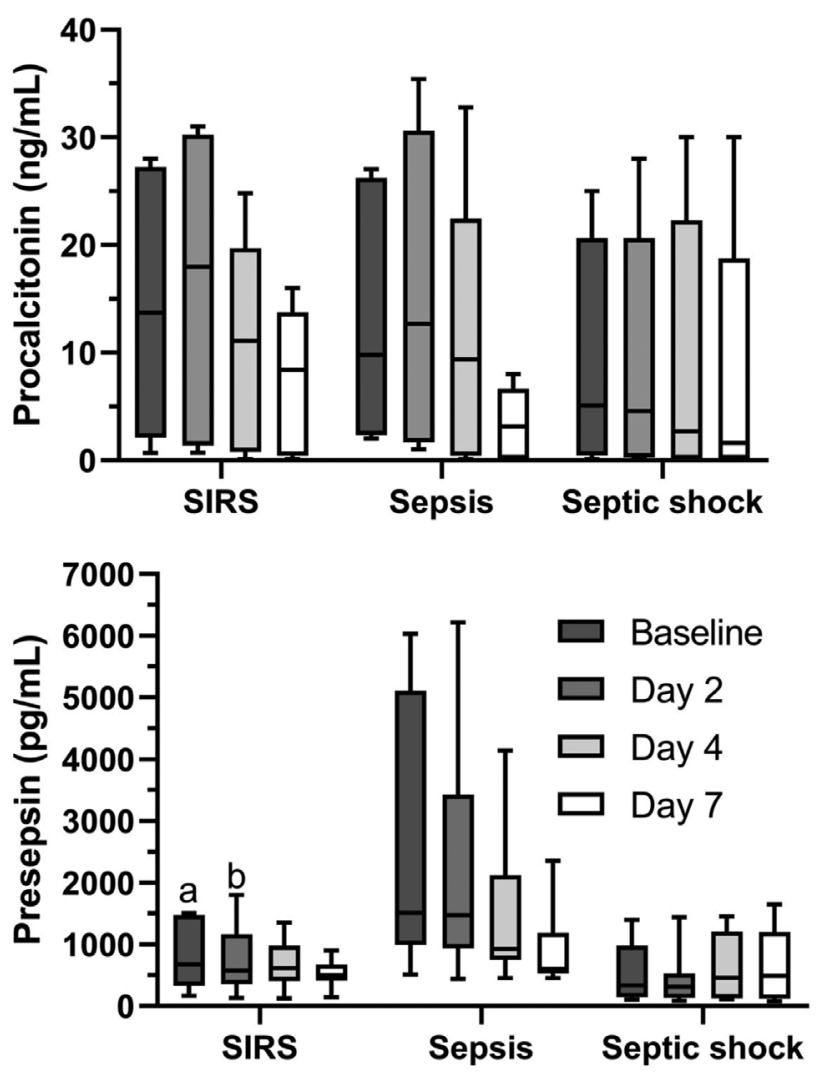

Figure 4. $P C T$ and presepsin values of patients with $\operatorname{SIRS}(n=9)$, sepsis $(n=6)$, and septic shock $(n=6)$. Data were presented as median with interquartile range of $25-75 \%$ with min-max values. There were overall decreases without significance in the PCT and presepsin values ( $p>0.05)$ except the presepsin values of patients with SIRS at baseline (a) and on day 2 (b) were significantly higher compared to those of septic shock $(p<0.05)$

PCT: Procalcitonin, SIRS: Systemic inflammatory response syndrome 


\begin{tabular}{|c|c|c|c|c|c|}
\hline \multicolumn{6}{|c|}{$\begin{array}{l}\text { Table 3. Correlation coeffic } \\
\text { measured at baseline and o } \\
\end{array}$} \\
\hline & & Baseline & Day 2 & Day 4 & Day 7 \\
\hline \multirow{4}{*}{ РCT } & Baseline & - & 0.87 & 0.63 & 0.63 \\
\hline & Day 2 & - & - & 0.88 & 0.83 \\
\hline & Day 4 & - & - & - & 0.90 \\
\hline & Day 7 & - & - & - & - \\
\hline & & \multicolumn{4}{|l|}{ PRE } \\
\hline & & Baseline & Day 2 & Day 4 & Day 7 \\
\hline \multirow{4}{*}{ PRE } & Baseline & - & 0.94 & 0.69 & 0.60 \\
\hline & Day 2 & - & - & 0.76 & 0.58 \\
\hline & Day 4 & - & - & - & 0.89 \\
\hline & Day 7 & - & - & - & - \\
\hline
\end{tabular}

to conventional biomarkers of sepsis (WBC, CRP, and PCT), the efficacy of presepsin at baseline and on days 2,4 , and 7 was examined and its prognostic value for prediction of mortality was determined. Compared to SIRS, sepsis and septic shock caused comparable increases in the APACHE II score of patients. The APACHE II score had no meaningful association with the studied sepsis biomarkers of CRP and WBC measured at baseline and PCT and presepsin values measured at baseline and on days 2, 4, and 7. Regarding the WBC and CRP parameters, SIRS, sepsis, and septic shock caused comparable changes.

Regarding mortality of studied participants, nonsurvivors had higher PCT values from baseline to day 7 but it was not reached statistical significance and some of the survivors had considerably high presepsin values from baseline to day 7 although this was not revealed as significant. Considering the type of disease from SIRS to sepsis and septic shock, there was a tendency to decrease in the PCT and presepsin values from baseline to day 7 although overall without any significance except a meaningful decrease in the presepsin values at baseline and on day 7 compared to SIRS. Correlation analyses revealed that both the PCT and presepsin values measured at baseline and on days 2, 4, and 7 had moderate-high associations, however, there was no similar association between the PCT and presepsin values measured on study time points except on day 7 . We considered this as the sign of a difference in the mechanism of elevation of PCT and presepsin biomarkers. After further studies considering mortality and subtypes of sepsis, these biomarkers can gain new prognostic value in the management of sepsis in the ICUs.

Sepsis remains a medical emergency and a major challenge in critical care. Early diagnosis and treatment with appropriate antimicrobial therapy is the most important factor for reducing its morbidity and mortality associated with sepsis (21). Blood culture is the gold standard for detecting microorganisms in the bloodstream but it has limited usefulness and requires several days for obtaining its results. Therefore, there isa need for biomarkers enabling early diagnosis of sepsis and the prediction of the prognosis (22). In the 1980s CRP, and in the 1990s PCT were discovered to be increased in the blood of bacterially infected patients (23). In recent years, presepsin has started to become a popular biomarker, with reports of higher sensitivity and specificity in the diagnosis of sepsis as compared to other biomarkers $(13,14,24)$.

Regarding APACHE II scoring to determine severity, Behnes et al. (25) have also reported an elevated first-day APACHE-II score in septic shock patients. In the study by Kweon et al. (26) significant variations in the APACHE-II scores of different patient groups were not observed. On the other hand, Shozushima et al. (27) have reported a correlation between the APACHE-II scores and presepsin levels of the 107 patients they studied.

Kweon et al. (26) also reported that mortality rates did not correlate with the presepsin levels on the first day. Masson et al. (28) have argued that the elevated presepsin levels but not the PCT levels were associated with the negative outcome during the hospital stay. Ulla et al (29) demonstrated a correlation between high presepsin values and hospital mortality. Also, Behnes et al. (2) demonstrated that presepsin levels were significantly higher in the non-survivors than the survivors.

\section{Study Limitations}

There are several limitations in the present study. The first limitation of the study was its retrospective nature. Secondly, this study included a limited number of patients with sepsis and septic shock. Thirdly, there were no daily measurements of the study parameters. Fourth, this study did not consider the importance of the type of microbiological agent. Fifth, because of the limited number of patients we couldn't investigate the relationship between the severity of sepsis, type of microorganism isolated from cultures and presepsin. Moreover, this study was performed in a single center with a small number of patients. It is not possible to reach solid conclusions on the diagnostic and prognostic values of presepsin on the basis of the severity of sepsis and mortality related to the SIRS, sepsis, and septic shock. Sepsis related definitions has been changed rapidly in recent years. However, there is a need for further studies according to the implications of the current study according to the new definitions. Presepsin reached several times increase in some patients and during management, their levels relatively decreased until day 7. Interestingly, its levels somewhat lower in the non-survivors and in patients with septic shock. presepsin 
levels considerablyhigher with sepsis compared to SIRS and septic shock.

\section{Conclusion}

During differential diagnosis, follow-up, and determination of mortality risk of patients for SIRS, sepsis and septic shock, findings of the current study support that presepsin possesses merit to be used as a biomarker after further studies investigating how presepsin increases and its relationship other clinical parameters.

\section{Authorship Contributions}

Concept: I.A., Ö.Ş., M.T. Design: I.A., Ö.Ş., M.T. Data Collection or Processing: I.A., Z.M.I.S., Ö.Ş., N.A., M.K. Analysis or Interpretation: I.A., Z.M.I.S., M.K., M.T., S.U. Literature Search: I.A., Z.M.I.S., M.K., M.T., S.U. Writing: i.A., Ö.Ş., M.T.

Conflict of Interest: The authors declared that there was no conflict of interest.

Financial Disclosure: The authors declared that this research did not receive any specific grant from funding agencies.

\section{References}

1. Kuter Ş, Canpolat C, Yılancıoglu K. Diagnostic role of SCD14subtype as a sepsis biomarker in febrile neutropenic pediatric oncology patients. ACU Sağllik Bil Derg 2018;9:395-400.

2. Singer $M$, Deutschman CS, Seymour CW, et al. The Third International Consensus Definitions for Sepsis and Septic Shock (Sepsis-3). JAMA 2016;315:801-10.

3. Huang CT, Ruan SY, Tsai YJ, Ku SC, Yu CJ. Clinical Trajectories and Causes of Death in Septic Patients with a Low APACHE II Score. J Clin Med. 2019;8:pii: E1064.

4. Martin-Loeches I, Levy MM, Artigas A. Management of severe sepsis: advances, challenges, and current status. Drug Des Devel Ther 2015;9:2079-88.

5. Bates DW, Sands K, Miller E, et al. Predicting bacteremia in patients with sepsis syndrome. Academic Medical Center Consortium Sepsis Project Working Group. I Infect Dis 1997;176:1538-51.

6. Giamarellos-Bourboulis EJ, Norrby-Teglund A, Mylona V, Savva A, Tsangaris I, Dimopoulou I et al. Risk assessment in sepsis: a new prognostication rule by APACHE II score and serum soluble urokinase plasminogen activator receptor. Crit Care 2012;16:R149.

7. Dellinger RP, Levy MM, Rhodes $A$, et al. Surviving sepsis campaign: international guidelines for management of severe sepsis and septic shock: 2012. Crit Care Med 2013;41:580637.

8. Crist-Crain M, Muller B. Procalcitonin in bacterial infectionshype, hope, more or less? Swiss Med Wkly 2005;135:45160.
9. Memar MY, Baghi HB. Presepsin: A promising biomarker for the detection of bacterial infections. Biomed Pharmacother 2019;111:649-56.

10. Kondo $Y$, Umemura $Y$, Hayashida $K$, Hara $Y$, Aihara $M$, Yamakawa K. Diagnostic value of procalcitonin and presepsin for sepsis in critically ill adult patients: a systematic review and meta-analysis. J Intensive Care 2019;7:22.

11. Yang HS, Hur M, Yi A, Kim H, Lee S, Kim SN. Prognostic value of presepsin in adult patients with sepsis: Systematic review and meta-analysis. PLoS One 2018;13:e0191486.

12. Endo S, Suzuki Y, Takahashi G, et al. Usefulness of presepsin in the diagnosis of sepsis in a multicenter prospective study. J Infect Chemother 2012;18:891-7.

13. Lu B, Zhang Y, Li C, et al. The utility of presepsin in diagnosis and risk stratification for the emergency patients with sepsis. Am J Emerg Med 2018;36:1341-5.

14. JATOS Study Group. Principle results of the Japanese trial to assess optimal systolic blood pressure in elderly hypertensive patients (JATUS). Hypertens Res 2008;31:2115-27.

15. Vincent JL. The Clinical Challenge of Sepsis Identification and Monitoring. PLoS Med 2016;13:e1002022.

16. Kaukonen KM, Bailey M, Pilcher D, Cooper DJ, Bellomo R. Systemic inflammatory response syndrome criteria in defining severe sepsis. N Engl J Med 2015;372:1629-38.

17. Bone RC, Balk RA, Cerra FB, et al. Definitions for sepsis and organ failure and guidelines for the use of innovative therapies in sepsis. The ACCP/SCCM Consensus Conference Committee. American College of Chest Physicians/Society of Critical Care Medicine. Chest 1992;101:1644-55.

18. Iskander KN, Osuchowski MF, Stearns-Kurosawa DJ, et al. Sepsis: multiple abnormalities, heterogeneous responses, and evolving understanding. Physiol Rev 2013;93:1247-88.

19. Nathan N, Sculier JP, Ameye L, Paesmans M, BogdanDragos G, Meert AP. Sepsis and Septic Shock Definitions in Patients With Cancer Admitted in ICU. J Intensive Care Med 2019:885066619894933 doi: 10.1177/0885066619894933

20. Singer M, Deutschman CS, Seymour CW, et al. The Third International Consensus Definitions for Sepsis and Septic Shock (Sepsis-3). JAMA 2016;315:801-10.

21. Balcl C, Sungurtekin H, Gürses E, Sungurtekin U, Kaptanoglu B. Usefulness of procalcitonin for diagnosis of sepsis in the intensive care unit. Crit Care 2003;7:85-90.

22. Hausfater P. Biomarkers and infection in the emergency unit. Med Mal Infect 2014;44:139-45.

23. Karzai W, Oberhoffer M, Meier-Hellmann A, Reinhart K. Procalcitonin-a new indicator of the systemic response to severe infections. Infection 1997;25:329-34.

24. Liu B, Chen YX, Yin Q, Zhao YZ, Li CS. Diagnostic value and prognostic evaluation of presepsin for sepsis in an emergency department. Crit Care 2013;17:R244. 
25. Behnes $M$, Bertsch $T$, Lepiorz $D$, et al. Diagnostic and prognostic utility of soluble CD 14 subtype (presepsin) for severe sepsis and septic shock during the first week of intensive care treatment. Crit Care 2014;18:507-20.

26. Kweon OJ, Choi JH, Park SK, Park AJ. Usefulness of presepsin (sCD14 subtype) measurements as a new marker for the diagnosis and prediction of disease severity of sepsis in the Korean population. Journal of Crit Care 2014;29:965-70.

27. Shozushima T, Takahashi G, Matsumoto N, Kojika M, Okamura Y, Endo S. Usefulness of presepsin (SCD14-ST) measurements as a marker for the diagnosis and severity of sepsis that satisfied diagnostic criteria of systemic inflammatory response syndrome. J Infect Chemother 2011;17:764-9.

28. Masson S, Caironi P, Spanuth E, Thomae R, Panigada M, Sangiorgi $G$ et al. Presepsin (soluble CD14 subtype) and procalcitonin levels for mortality prediction in sepsis: data from the Albumin Italian Outcome Sepsis trial. Crit Care 2014;18:R6.

29. Ulla M, Pizzolato E, Lucchiari M, Loiacono M, Soardo F, Forno $D$ et al. Diagnostic and prognostic value of presepsin in the management of sepsis in the emergency department: a multicenter prospective study. Crit Care 2013;17:R168. 